Indexed by

\section{Scopus}

Crossref

KOBSON

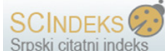

8. Google

\title{
INVESTIGATE THE CARBON FOOTPRINTS OF THREE INTERMEDIATE FLOORING SYSTEMS: CROSS-LAMINATED TIMBER, SOLID CONCRETE, AND HOLLOW-CORE PRECAST CONCRET
}

\section{Jenan Abu Qadourah}

Department of Architecture and Building Technology,

Faculty of Engineering, Mutah University,

P.O. Box 7, Al-Karak, 61710 Jordan
Ala'a M. Al-Falahat

Mechanical Engineering

Department,

Faculty of Engineering,

Mutah University,

P.O Box 7, Al-Karak,

61710 Jordan

\author{
Saad S. Alrwashdeh \\ Mechanical Engineering \\ Department, \\ Faculty of Engineering, \\ Mutah University, \\ P.O Box 7, Al-Karak \\ 61710 Jordan
}

Key words: sustainable materials, cross-laminated timber, life-cycle assessment, environmental impact, cradle-to-gate, embodied energy, greenhouse gas emissions

doi:10.5937/jaes0-32783

Cite article:

Abu Qadourah J., M. Al-Falahat A., S. Alrwashdeh S. (2022) INVESTIGATE THE CARBON FOOTPRINTS OF THREE INTERMEDIATE FLOORING SYSTEMS: CROSS-LAMINATED TIMBER, SOLID CONCRETE, AND HOLLOW-CORE PRECAST CONCRET, Journal of Applied Engineering Science, 20(2), 377 - 385, DOI:10.5937/ jaes0-32783

Online aceess of full paper is available at: www.engineeringscience.rs/browse-issues 


\title{
INVESTIGATE THE CARBON FOOTPRINTS OF THREE INTERMEDIATE FLOORING SYSTEMS: CROSS-LAMINATED TIMBER, SOLID CONCRETE, AND HOLLOW-CORE PRECAST CONCRETE
}

\author{
Jenan Abu Qadourah', Ala'a M. Al-Falahat', Saad S. Alrwashdeh ${ }^{2}$ \\ ${ }^{1}$ Department of Architecture and Building Technology, Faculty of Engineering, Mutah University, \\ P.O. Box 7, Al-Karak, 61710 Jordan \\ ${ }^{2}$ Mechanical Engineering Department, Faculty of Engineering, Mutah University, P.O Box 7, Al-Karak 61710 \\ Jordan
}

This paper evaluates and compares the embodied energy and embodied carbon using a Life Cycle Assessment (LCA) approach for three different intermediate floor structures, all of which use prefabricated materials-cross-laminated timber (CLT), precast hollow-core concrete, and solid concrete-to decide which floor construction materials have less environmental impact for use in the construction of a semi-detached house in the UK. The Inventory of Carbon \& Energy (ICE) and the Carbon Calculator tool were used to calculate the carbon footprint from "cradle to grave" to determine whether the use of a CLT solution provides improved environmental performance over the traditional concrete solutions. The carbon footprint results indicate that the use of a hollow-core precast concrete floor system emits less carbon than the other two systems, although the concrete requires more fossil fuel input than the timber during the manufacturing process, so based on this, the footprint from cradle to gate for the timber was expected to be the less than that of the concrete. However, the results show the opposite; this is because of the differences in the material quantities needed in each system.

Key words: sustainable materials, cross-laminated timber, life-cycle assessment, environmental impact, cradle-to-gate, embodied energy, greenhouse gas emissions

\section{INTRODUCTION}

Over the past few years, there has been growing concern in the world about the increase of greenhouse gas (GHG) emissions, including those of $\mathrm{CO}_{2}$ [1-5]. The building construction sector is the main source of $\mathrm{CO} 2$ emissions, as more than $40 \%$ of the global GHG outputs and energy consumption are produced through building construction and operation [6-9]. Overall, more than half of the embodied carbon in construction is connected to the materials consumption [10-13], as it uses $40 \%$ of the total gravel, sand, and raw stone consumed worldwide [14-18]. Moreover, these materials must be transported long distances, which leads to increased fuel consumption and produces a lot of greenhouse gases [11]. Accordingly, a wide range of embodied carbon mitigation solutions focus on reducing the use of materials from carbon-intensive supply chains [6, 19-22]. These include solutions that aim to reduce excessive material usage through "light weighting" to reduce waste material on site; solutions to optimize the usable life of materials by increasing the life of existing structures and constructing new ones to be adaptable and simple to dismantle (enabling materials and components to be reused); or replacement of materials and building products with alternatives that have low-carbon supply chains $[20,23]$. In the UK, this has been addressed by the Building Regulations Part $L$ with standards to reduce household energy use [17]. Although in-use energy is significant, a building has a much wider range of associated energy or carbon. Materials, for example, require energy for their manufacturing, transport to site, disposal, and end-of-life demolition (see Figure1). This is known as the embodied energy of material from cradle to grave [24, 25].

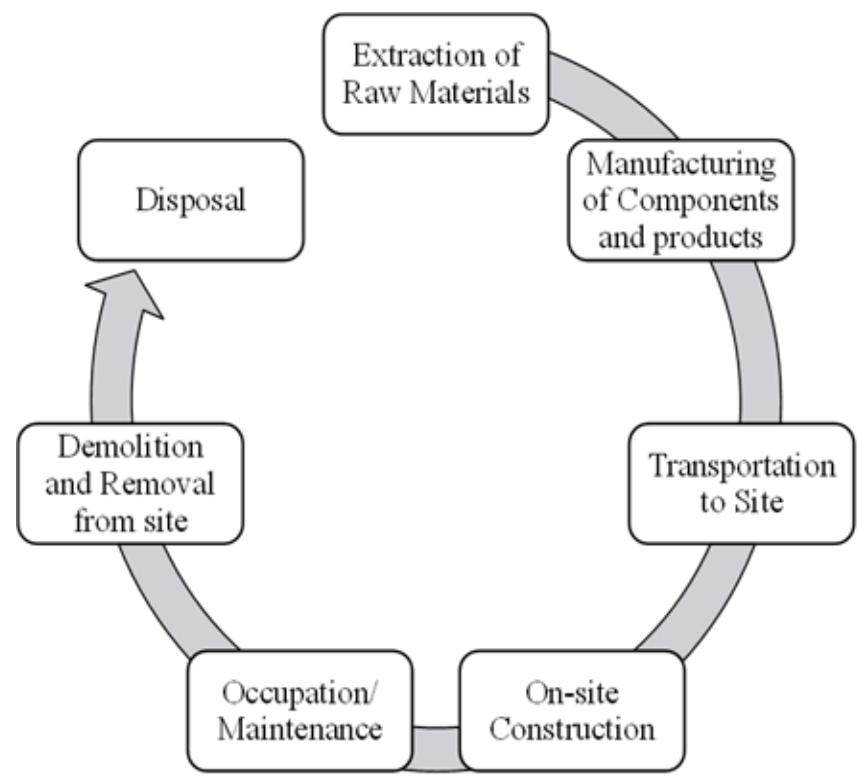

Figure 1: Building construction life cycle process from cradle to grave

Although this standard gives a comprehensive overview of the associated GHG emissions for a material, making it easy to compare and identify an area where the 
impacts could be reduced, it is relatively complex to calculate. Hammond and Jones [26] collated public source data on the embodied energy and carbon of many common construction materials, publishing them in the Inventory of Carbon \& Energy (ICE). The figures used in ICE are from cradle to gate for most of the materials. The Environmental Agency has used this to develop a Carbon Calculator and make some improvements to calculating the carbon footprint from cradle to grave; for example, it considers transport of materials and workers to the site, site energy use, and the disposal of construction waste (cradle to grave) [27]. Using these tools, the cradle-to-grave GHG emissions for three different sound insulation prefabricated floor structures for a semi-detached house in the UK were investigated to determine whether the use of a cross-laminated timber (CLT) solution provides improved environmental performance over the traditional concrete solutions. Past construction has heavily involved concrete and steel, both of which are highly energy-intensive when combining the materials, production, transport, and construction stages. However, timber has the potential to avoid the majority of fossil fuel consumption and $\mathrm{CO}_{2}$ release related to these conventional materials [28]. In the United Kingdom, the usage of timber in construction is increasing. Timber frame systems accounted for nearly a quarter of all UK housing starts in 2016, up nearly $9 \%$ from the previous year, according to the Structural Timber Association, compared to 3.6 percent growth in non-timber frame systems [29]. Besides, engineered wood products, such as CLT and glulam, are now facilitating a new generation of larger timber buildings in the UK and many other countries around the world, including industrial and commercial buildings [28, 29].

\section{METHODOLOGY AND KEY ASSUMPTION}

This paper evaluates and compares the embodied energy (EE) and embodied carbon (EC) using an LCA approach for three different intermediate floor structures, all of which use prefabricated materials-CLT, precast hollow-core concrete, and solid concrete-to decide which floor construction materials have less environmental impact for use in the construction of a semi-detached house. The components of each floor system are illustrated in Figure 2, and more details can be accessed in
Appendices 1, 2, and 3. Full life cycle, from 'cradle to grave' system boundary has been applied in this study, which includes material extraction, manufacturing, transportation, on-site construction and installation, and the demolition phase [27]. The operation and maintenance stage of the LCA has not been considered, as it is assumed the energy required when the floor is in use will be similar for all materials. A full life cycle assessment from cradle to grave gives a more realistic and reliable environmental impact than consideration of embodied energy and carbon from cradle to gate alone [32-34]. Cradle to gate assessment does not give a complete picture of a product that can be compared to other materials in a meaningful way, because other features of the various material alternatives' use-phase and end-oflife are not included [35]. As mentioned earlier, the Environmental Agency Carbon Calculator has been used to calculate the embodied energy and embodied carbon. Inventory data has been collected from the Carbon \& Energy (ICE) database to determine emissions factors for other materials and for end of life scenarios [26]. To allow a simple assessment, the floor outline is assumed to be rectangular and have a total area of approximately $150 \mathrm{~m} 2$, with dimensions of $10 \mathrm{~m}$ wide by $15 \mathrm{~m}$ long. The site is assumed to be located in Cardiff, CF24 4BZ. For each system, the components have been defined, and the required tonnage, distance and travel mode from the manufacturer, tonnage wasted, disposal mechanisms, and distance and travel mode to the waste processing site of each component have been specified (see Appendices 1-2). This information is then input into the Environmental Agency Carbon Calculator to calculate the tons of $\mathrm{CO}_{2}$ emitted for each system from cradle to grave. The precast hollow-core concrete floor structure comprises a pre-cast hollow-core concrete slab, a leveling screed, a resistance layer like rubber, and a vapor control layer. The slab should be tightly abutted; all joints should be filled with grout, assumed to be a mortar; and the thickness should be $0.15 \mathrm{~m}$. The hollow segments of the precast slab should be distributed over a minimum of 80 $\%$ of the slab. According to the manufacturing company, the hollow-core concrete slabs are available in a range of widths for spans up to $15 \mathrm{~m}$ [31]. The precast solid concrete floor is assumed to have the same components used in the hollow-core concrete floor system, except
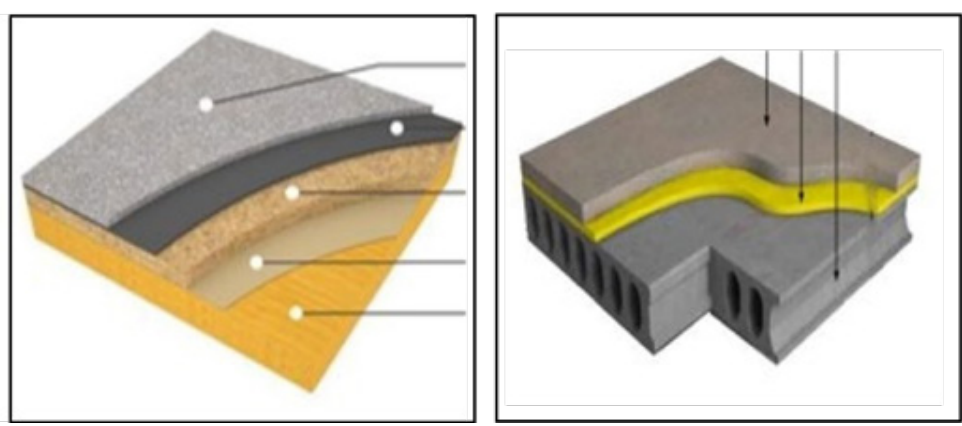

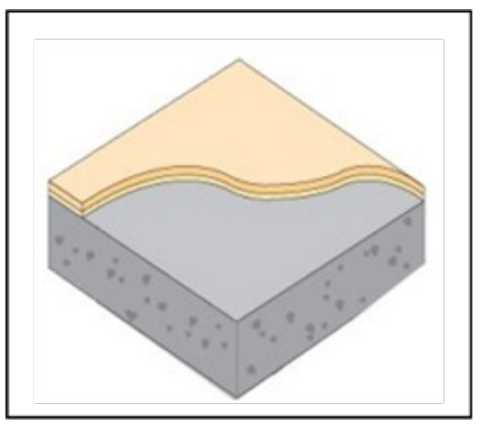

Figure 2: (A) The components of a CLT floor [30]; (B) The components of a hollow-core concrete floor system [31]; (C) The components of a solid concrete floor system [31] 
that the thickness of the concrete layer must be $0.10 \mathrm{~m}$ instead of $0.15 \mathrm{~m}$, and each slab can be prefabricated with a size of up to $6 \times 3 \mathrm{~m}$. For this site, the slabs' dimensions are assumed to be $5 \times 5 \mathrm{~m}$; accordingly, six slabs are needed to cover the floor area; the joint between the slabs should be filled with in-situ mortar [31]. The studied floor systems are assumed to be installed by hand; however, the energy use of heavy equipment like a crane is need-ed. The crane is hired from Gullivers Company, which is $5.5 \mathrm{~km}$ from the construction site. Moreover, the hollow-core concrete floor and the solid concrete floor need a mortar mixer in addition to the crane. Regarding the project duration and site accommodation, the same assumptions are made for the three systems: that the project duration is three weeks; eight people are permanently on site, as this is a small project; and the main used elements are prefabricated. Accordingly, accommodation is needed for three weeks. For the waste in the three systems, recycling is prioritized, and the closest processing plants to the site have been selected for use in the analysis. Waste figures are assumed to be 5 $\%$ or $10 \%$ according to average figures for each material unless the material is supplied in specified amounts for which the waste can be calculated exactly.

\section{RESULTS}

Overall, as illustrated in Table 1, the cradle-to-grave CO2 emissions of the hollow concrete floor are the lowest, while the solid concrete floor has the highest carbon footprint. The $\mathrm{CO}_{2}$ emissions of the solid precast concrete floor are $25 \%$ higher than those of the hollow-core concrete and $6 \%$ higher than those of the CLT floor, and the highest carbon footprint among all these floor systems is during the manufacturing process, which is from cradle to gate. From gate to site, the carbon emissions are the lowest, while from site to grave, the carbon footprint is the same for all the studied floor systems; this is because the three types are prefabricated locally, and the site accommodation and project duration are the same (see Figure 3).

\section{DISCUSSION}

The carbon footprint results indicate that the use of a hollow-core precast concrete floor system emits less carbon than the other two systems. Based on the fact that concrete requires more fossil fuel input than timber during the manufacturing process, the footprint from cradle to gate for the timber was expected to be the less than that of the concrete. However, the results show the opposite; this is because of the differences in the material quantities needed in each system. And this is clear through comparing the hollow-core system with the solid-core one, as the same material is used with the same embodied energy, yet different amounts of $\mathrm{CO}_{2}$ are emitted: hollow-core concrete produces 4 tons, and solid concrete produces 6.6 tons (see Table 2). Another factor that affects the carbon footprint in these three systems is the use of miscellaneous materials. In all three systems, a rubber insulation layer is used, while the CLT floor additionally uses wood fiber insulation to increase the efficiency of sound insulation, which increases the carbon footprint. On the other hand, most of the carbon footprint resulted from the finishing layer in the concrete (solid and hollow-core concrete) systems. However, from gate to site, there are no big differences between the three systems. This is because all the material was manufactured locally, so the amount of fossil fuel consumed to transport the material to the site is relatively low. Also, from site to grave, the carbon footprint is low because all the systems are prefabricated, which leads to a significant decrease in the construction time and the on-site waste compared to in-situ systems; moreover, there are many disposal sites near the construction site.

Overall, as the main function for these floors is to isolate the sound, this leads to the use of more layers with more thickness and different materials in the CLT floor, which causes an in-crease in the carbon footprint of this system, although the timber has less embodied energy than the concrete.

Table 1: Cradle to grave carbon footprint for the CLT, hollow-core concrete, and solid concrete floors

\begin{tabular}{|c|c|c|c|c|}
\hline FLOOR TYPE & $\begin{array}{c}\text { CRADLE TO } \\
\text { GATE } \\
\left(\text { TON CO }_{2}\right)\end{array}$ & $\begin{array}{c}\text { GATE TO SITE } \\
\left(\text { TON CO }_{2}\right)\end{array}$ & $\begin{array}{c}\text { SITE TO } \\
\text { GRAVE } \\
\left(\text { TON CO }_{2}\right)\end{array}$ & $\begin{array}{c}\text { CRADLE TO } \\
\text { GRAVE } \\
\left(\text { TON CO }_{2}\right)\end{array}$ \\
\hline $\begin{array}{c}\text { CLT FLOOR } \\
\text { HOLLOW-CORE CONCRETE } \\
\text { FLOOR }\end{array}$ & 16.9 & 0.021 & 2.5 & 19.4 \\
\hline SOLID CONCRETE FLOOR & 18.3 & 0.023 & 2.5 & 15.7 \\
\hline
\end{tabular}


Table 2: Embodied CO2 by energy consumption and material quantities needed for the main material in each floor system

\begin{tabular}{|c|c|c|c|}
\hline & TIMBER & CONCRETE HOLLOW-CORE SLAB & SOLID CONCRETE SLAB \\
\hline $\begin{array}{c}\text { EMBODIED ENERGY } \\
\left(\text { TCO }_{2} \text { TON MATERIAL) }\right.\end{array}$ & 0.31 & 0.33 & 0.33 \\
\hline $\begin{array}{c}\text { QUANTITY NEEDED } \\
\text { (TONS) }\end{array}$ & 10.2 & 4 & 6.6 \\
\hline
\end{tabular}

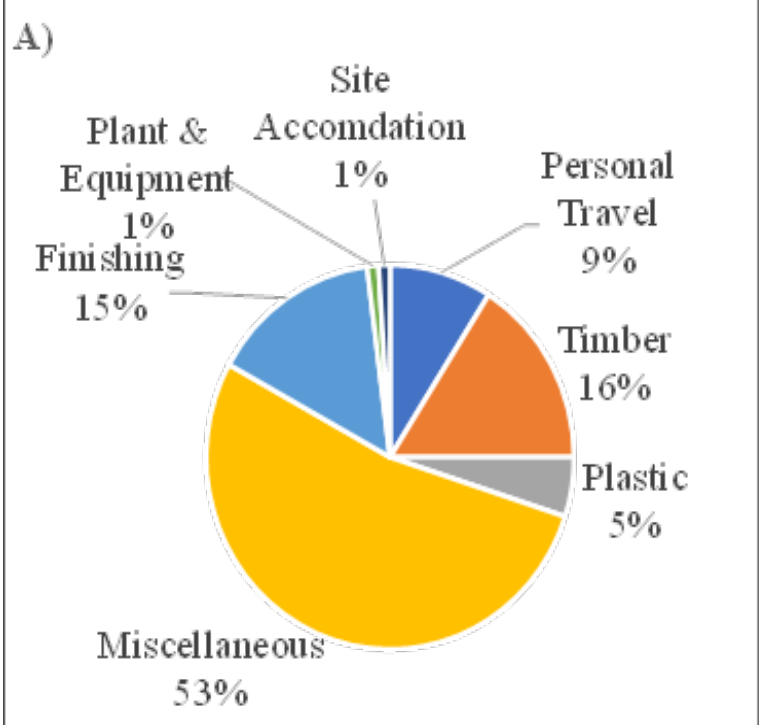

B)

Site
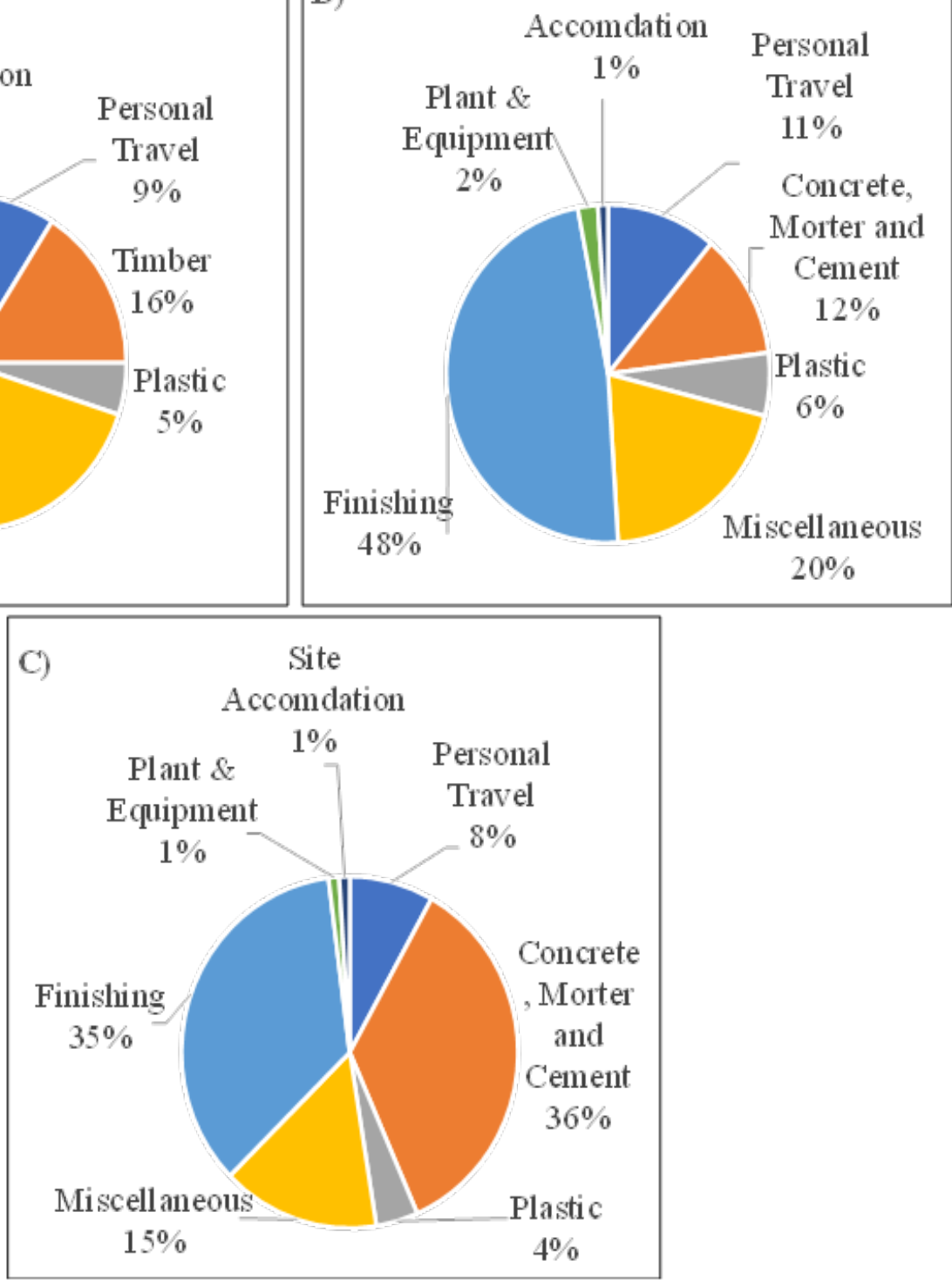

Figure 3: (A) Carbon emissions by process and material for the CLT floor, (B) Hollow-core concrete floor, (C) Solid concrete floor 


\section{CONCLUSION}

Although the carbon footprint of the hollow-core floor concrete systems is lowest, it is difficult to conclude which type of flooring has the lowest environmental impacts. This is due to the other factors involved in the life cycle of the element, such as the life expectancy of these systems, their need for maintenance, and the effect of each floor on in-use energy. However, different aspects can be controlled to decrease the carbon footprint, such as using local materials with less embodied energy and with less material needed without affecting the efficiency of the structure, as well as using recyclable material. In general, the prefabricated systems can be very efficient in decreasing the carbon footprint on the site by decreasing the duration of construction and de-creasing the amount of on-site waste, as well as the use of equipment. Overall, it is important to understand the GHG emissions associated with the various parts of the building process; however, the techniques for doing this are still in their infancy. While these are being developed, cradle-to-site analysis is still a useful tool to identify key areas of improvement when considering potential element systems.

\section{REFERENCES}

1. Change, I. (2014). Climate Change 2013 - The Physical Science Basis.

2. Alrwashdeh, S.S. (2018). Assessment of photovoltaic energy production at different locations in Jordan. International Journal of Renewable Energy Research 8, 797-804.

3. Alrwashdeh, S.S. (2018). Modelling of operating conditions of conduction heat transfer mode using energy 2D simulation. International Journal of Online Engineering 14, 200-207.

4. Alrwashdeh, S.S., Alsaraireh, F.M., Saraireh, M.A., Markötter, H., Kardjilov, N., Klages, M., Scholta, J., and Manke, I. (2018). In-situ investigation of water distribution in polymer electrolyte membrane fuel cells using high-resolution neutron tomography with $6.5 \mu \mathrm{m}$ pixel size. AIMS Energy 6, 607-614.

5. Alrwashdeh, S.S., Markötter, H., Haußmann, J., Scholta, J., Hilger, A., and Manke, I. (2016). X-ray tomographic investigation of water distribution in polymer electrolyte membrane fuel cells with different gas diffusion media. In ECS Transactions, Volume 72, 8 Edition., pp. 99-106.

6. Asif, M., Muneer, T., and Kelley, R. (2007). Life cycle assessment: A case study of a dwelling home in Scotland. Building and Environment 42, 1391-1394.

7. Brown, I.A., Hammond, G.P., Jones, I.C., and Rogers, F.J. (2009). Greening the UK building stock: Historic trends and low carbon futures 1970-2050. Trans Can Soc Mech Eng Transactions of the Canadian Society for Mechanical Engineering 33, 89-104.
8. Hammond, G., and Jones, C.I. (2010). Embodied carbon: the concealed impact of residential construction. (Springer).

9. Berardi, U. (2017). A cross-country comparison of the building energy consumptions and their trends. Resources, Conservation and Recycling 123, 230 241.

10. Al-Falahat, A.a.M., Qadourah, J.A., Alrwashdeh, S.S., khater, R., Qatlama, Z., Alddibs, E., and Noor, M. (2022). Energy performance and economics assessments of a photovoltaic-heat pump system. Results in Engineering 13.

11. Giesekam, J., Barrett, J., Owen, A., and Taylor, P. (2014). The greenhouse gas emissions and mitigation options for materials used in UK construction. Energy Build. Energy and Buildings 78, 202-214.

12. Onat, N., and Kucukvar, M. (2020). Carbon footprint of construction industry: A global review and supply chain analysis. Renewable and Sustainable Energy Reviews 124, 109783.

13. Hertwich, E. (2021). Increased carbon footprint of materials production driven by rise in investments. Nature Geoscience 14, 1-5.

14. Al-falahat, A. (2021). Examination of the Dynamic Behaviour of the Composite Hollow Shafts Subject to Unbalance. International Journal of Mechanical Engineering and Robotics Research 10.

15. Al-Falahat, A.a.M. (2021). Examination of the Dynamic Behaviour of the Composite Hollow Shafts Subject to Unbalance. International Journal of Mechanical Engineering and Robotics Research, 572576.

16. Dixit, M.K., Fernández-Solís, J.L., Lavy, S., and Culp, C.H. (2010). Identification of parameters for embodied energy measurement: A literature review. ENB Energy \& Buildings 42, 1238-1247.

17. Krausmann, F., Gingrich, S., Eisenmenger, N., Erb, K.H., Haberl, H., and Fischer-Kowalski, M. (2009). Growth in global materials use, GDP and population during the 20th century. ECOLOGICAL ECONOMICS 68, 2696-2705.

18. de la Rue du Can, S., and Price, L. (2008). Sectoral trends in global energy use and greenhouse gas emissions. Energy Policy 36, 1386-1403.

19. Government, H. (2010). Low Carbon Construction, Innovation \& Growth Team.

20. Ramesh, T., Prakash, R., and Shukla, K.K. (2010). Life cycle energy analysis of buildings: An overview. Energy and Buildings 42, 1592-1600.

21. IPCC), I.P.o.C.C. (2014). Climate Change 2014: Synthesis Report. Contribution of Working Groups I, II and III to the Fifth Assessment Report of the Intergovernmental Panel on Climate Change. (IPCC). 
22. Giesekam, J., Barrett, J.R., and Taylor, P. (2015). Construction sector views on low carbon building materials. Building Research \& Information 44, 423444.

23. Robertson, A.B., Lam, F.C.F., and Cole, R.J. (2012). A Comparative Cradle-to-Gate Life Cycle Assessment of Mid-Rise Office Building Construction Alternatives: Laminated Timber or Reinforced Concrete. Buildings 2, 245-270.

24. Zhou, S., Guo, Z., Ding, Y., Dong, J., Le, J., and Fu, J. (2021). Effect of Green Construction on a Building's Carbon Emission and Its Price at Materialization. Sustainability 13, 642.

25. Wang, Z., Liu, Y., and Shen, S. (2021). Review on building life cycle assessment from the perspective of structural design. Journal of Asian Architecture and Building Engineering Journal of Asian Architecture and Building Engineering, 1-17.

26. Liu, H., Li, J., Sun, Y., Wang, Y., and Zhao, H. (2020). Estimation Method of Carbon Emissions in the Embodied Phase of Low Carbon Building. Adv. Civ. Eng. Advances in Civil Engineering 2020.

27. Francart, N., and Malmqvist, T. (2020). Investigation of maintenance and replacement of materials in building LCA. IOP Conference Series: Earth and Environmental Science 588, 032027.

28. Hammond, G., and Jones, C. (2010). Embodied carbon: the concealed impact of residential construction. Volume 31. (Green Energy and Technology), pp. 367-384.
29. Hammond, G., and Jones, C. (2011). Embodied carbon : the Inventory of Carbon and Energy (ICE), (Bracknell: BSRIA).

30. Spear, M., Hill, C., Norton, A., and Price, C. (2019). Wood in Construction in the UK: An Analysis of Carbon Abatement Potential. (Bangor University: The BioComposites Center).

31. (STA), S.T.A. (2017). Annual survey of UK structural timber markets. In Market report 2016.

32. Greenspec (2020). Crosslam timber/ CLT - Intermediate floor construction. Volume 2020.

33. Supplier, J. (2020). Insulation for ground floors. Volume 2020. ( Designing Buildings Wiki).

34. Lyons, A. (2020). Materials for architects and builders.

35. Cadorel, X., and Crawford, R. (2019). Life cycle analysis of cross laminated timber in buildings: a review.

36. Moncaster, A.M., and Symons, K.E. (2013). A method and tool for cradle to grave embodied carbon and energy impacts of UK buildings in compliance with the new TC350 standards. ENB Energy \& Buildings 66, 514-523.

37. Lugt, P., Bongers, F., and Vogtlander, J. (2016). ENVIRONMENTAL IMPACT OF CONSTRUCTIONS MADE OF ACETYLATED WOOD.

\section{APPENDIXES}

Appendix 1: summary of assumptions and calculations used to estimate the carbon footprint from cradle to grave for the CLT Floor system

\begin{tabular}{|c|c|c|c|c|c|}
\hline Component & $\begin{array}{c}\text { Screed } \\
\text { (cement and } \\
\text { sand) }\end{array}$ & Rubber & $\begin{array}{l}\text { Wood fiber } \\
\text { insulation }\end{array}$ & $\begin{array}{c}\text { Vapor } \\
\text { control layer } \\
\text { (polyethylene) }\end{array}$ & 5-layer Crosslam timber \\
\hline Volume required & $\begin{array}{l}0.025 * 10^{*} 15 \\
=3.75 \mathrm{~m}^{3}\end{array}$ & $\begin{array}{c}0.012 * 10 * 15= \\
1.8 \mathrm{~m}^{3}\end{array}$ & $\begin{array}{c}0.01 * 10 * 15= \\
1.5 \mathrm{~m}^{3}\end{array}$ & $\begin{array}{c}0.003 * 10 * 15= \\
0.45 \mathrm{~m}^{3}\end{array}$ & $\begin{array}{c}0.13 * 10^{*} 15= \\
19.5 \mathrm{~m}^{3}\end{array}$ \\
\hline $\begin{array}{c}\text { Density } \\
\left(\text { tons } / \mathrm{m}^{3} \text { ) }\right.\end{array}$ & 1.2 & 1.5 & 0.05 & 0.92 & 0.5 \\
\hline Wastage rate & $5 \%$ & $5 \%$ & $1 \%$ & $10 \%$ & $5 \%$ \\
\hline $\begin{array}{c}\text { Quantity } \\
\text { tones (with } \\
\text { wastage rate) }\end{array}$ & $\begin{array}{c}1.2 * 3.75+ \\
(1.2 * 3.75 * 5 \%) \\
=4.75\end{array}$ & $\begin{array}{c}1.5 * 1.8+ \\
(1.5 * 1.8 * 5 \%)= \\
2.835\end{array}$ & $\begin{array}{c}0.05 * 1.5+ \\
(0.05 * 9 * 1 \%)= \\
0.12\end{array}$ & $\begin{array}{c}0.45 * 0.92+ \\
(0.45 * 0.92 * 10 \%) \\
=0.45\end{array}$ & $\begin{array}{c}19.5 * 0.54+ \\
(19.5 * 0.5 * 5 \%)= \\
10.2\end{array}$ \\
\hline $\begin{array}{l}\text { Embodied energy } \\
\text { tCO2/ton material }\end{array}$ & 0.6 & 2.85 & 0.93 & 1.93 & 0.31 \\
\hline $\begin{array}{l}\text { Footprint (tons } \\
\text { fossil CO2e } \\
\text { (embodied) }\end{array}$ & 2.85 & 8.123 & 1.95 & 0.9 & 3.1 \\
\hline Embodied CO2 & \multicolumn{3}{|c|}{16.90 tons $\mathrm{CO} 2$} & \multicolumn{2}{|c|}{ (Cradle to gate) (material +waste) } \\
\hline Manufacturing site & \begin{tabular}{|} 
Roath Dock \\
Road. Cardiff. \\
C F10 4ED
\end{tabular} & $\begin{array}{l}\text { Penarth. CF64 } \\
\text { 2LA }\end{array}$ & $\begin{array}{l}\text { Wellwood, } \\
\text { Cardiff. } \\
\text { CF23 9JR }\end{array}$ & $\begin{array}{c}\text { Leighton Buzzard, } \\
\text { LU7 4TZ }\end{array}$ & $\begin{array}{l}\text { London } \\
\text { SE12NL }\end{array}$ \\
\hline $\begin{array}{c}\begin{array}{c}\text { Distance (gate to } \\
\text { site) }\end{array} \\
\end{array}$ & $6.9 \mathrm{~km}$ & 7.4 & 4.16 & 223.2 & 247.8 \\
\hline Mode of travel & Road & Road & Road & Road & Road \\
\hline $\begin{array}{l}\text { Footprint (tons } \\
\text { fossil CO2e } \\
\text { (transport) }\end{array}$ & 0.004 & 0.003 & 0.004 & 0.007 & 0.003 \\
\hline Total & \multicolumn{5}{|c|}{0.021 tons $\mathrm{CO} 2$ by Transport of Materials (gate to site) Cradle to site $=16.92$ tons $\mathrm{CO} 2$} \\
\hline
\end{tabular}




\begin{tabular}{|c|c|c|c|c|c|c|c|}
\hline Disposal method & \multicolumn{2}{|c|}{$\begin{array}{l}\text { Reuse / } \\
\text { recycled } \\
\text { CF24 2QS }\end{array}$} & \multicolumn{2}{|c|}{$\begin{array}{c}\text { recycled CF } 14 \\
1 \mathrm{DO}\end{array}$} & $\begin{array}{l}\text { Reuse /recycled } \\
\text { CF10 4LY }\end{array}$ & $\begin{array}{c}\text { Landfill CF11 } \\
6 \mathrm{EU}\end{array}$ & $\begin{array}{l}\text { Recycling /reuse } \\
\text { CF10 4LY }\end{array}$ \\
\hline $\begin{array}{c}\text { Distance to } \\
\text { disposal }(\mathrm{km})\end{array}$ & \multicolumn{2}{|c|}{3.8} & \multicolumn{2}{|c|}{4.3} & 4 & 3.2 & 4 \\
\hline Mode of travel & \multicolumn{2}{|c|}{ Road } & \multicolumn{2}{|c|}{ Road } & Road & Road & Road \\
\hline Tons wasted & \multicolumn{2}{|c|}{0.39} & \multicolumn{2}{|c|}{0.135} & 0.75 & 0.0414 & 0.49 \\
\hline total & \multicolumn{7}{|c|}{1.8 tons wasted } \\
\hline Waste & \multicolumn{5}{|c|}{0.00} & \multicolumn{2}{|r|}{ tons $\mathrm{CO} 2$} \\
\hline Equipment & $\begin{array}{l}\text { Power } \\
\text { source }\end{array}$ & Hol & in use & $\begin{array}{l}\text { Equipment } \\
\text { plant } \\
\text { location }\end{array}$ & $\begin{array}{c}\text { Distance } \\
\text { to equipment } \\
\text { hire plant }\end{array}$ & \multicolumn{2}{|r|}{ Came travel I/day } \\
\hline Crane & Diesel & $\begin{array}{l}\text { Wor } \\
\text { Ed } \\
\text { Nee } \\
\text { for } \\
(50\end{array}$ & $\begin{array}{l}\text { ig For } 5 \\
\text { urs } \\
\text { day } \\
101 / \text { day } \\
\text { days. } \\
\text { itters) }\end{array}$ & $\begin{array}{l}\text { Gullivers } \\
\text { hire, } \\
\text { CF118TX }\end{array}$ & 5.5 & $\begin{array}{l}\text { (One to trave } \\
\text { (10 lit }\end{array}$ & $\begin{array}{l}\text { For } 2 \text { days } \\
\text { to the site one travel from the site) } \\
\text { rs for } 11 \mathrm{~km} \text { travel distance) }\end{array}$ \\
\hline \multicolumn{8}{|c|}{$\begin{array}{l}\text { One crane is needed in the site construction which travel from and to the site we time and stay in the site during the } 7 \text {-working } \\
\text { day consumed 51/day for travailing and for working }\left(5.5^{*} 2\right)\end{array}$} \\
\hline $\begin{array}{c}\text { Plant Emissions } \\
\text { tons } \mathrm{CO} 2\end{array}$ & \multicolumn{7}{|c|}{0.3 tons $\mathrm{CO} 2$} \\
\hline \multicolumn{6}{|c|}{ Personnel Travel } & \multicolumn{2}{|r|}{ Work duration } \\
\hline \multicolumn{6}{|c|}{ Small (fewer than 8 people permanently on site) } & \multicolumn{2}{|r|}{ three weeks } \\
\hline \multicolumn{6}{|c|}{ Personal travel tons $\mathrm{CO}$, } & \multicolumn{2}{|r|}{2 tons $\mathrm{CO} 2$} \\
\hline \multicolumn{8}{|c|}{ Site accommodations } \\
\hline \multicolumn{6}{|c|}{$5 \mathrm{I} /$ day for 12 days, $100 \mathrm{~km}$} & \multicolumn{2}{|r|}{0.156} \\
\hline \multicolumn{6}{|c|}{ Electricity $30 \mathrm{kwh}$} & \multicolumn{2}{|r|}{0.013} \\
\hline \multicolumn{6}{|c|}{ Site accommodation tons $\mathrm{CO}$, } & \multicolumn{2}{|r|}{0.2 tons $\mathrm{CO}$} \\
\hline \multicolumn{6}{|c|}{$\begin{array}{l}\text { Site to grave tons } \mathrm{CO} 2 \text {. Waste tons } \mathrm{CO}_{2}+\text { Plant Emissions } \\
\text { tons } \mathrm{CO} 2+\text { Personal travel tons } \mathrm{CO} 2 \text {, Site accommodation tons } \mathrm{CO} 2\end{array}$} & \multicolumn{2}{|r|}{$\begin{array}{c}0.2+21 \% 3+0= \\
2.5 \text { tons } \mathrm{CO}_{2}\end{array}$} \\
\hline \multicolumn{6}{|c|}{ Cradle to grave tons $\mathrm{CO} 2$. } & \multicolumn{2}{|r|}{19.4 tons $\mathrm{CO}_{2}$} \\
\hline
\end{tabular}

Appendix 2: summary of assumptions and calculations used to estimate the carbon footprint from cradle to grave for the precast hollow core concrete floor system

\begin{tabular}{|c|c|c|c|c|c|}
\hline Component & $\begin{array}{c}\text { Screed (sand and } \\
\text { cement) }\end{array}$ & Rubber & $\begin{array}{l}\text { Vapor control } \\
\text { layer }\end{array}$ & $\begin{array}{l}\text { Hollow-core Concert } \\
\text { Slabs }\end{array}$ & Mortar \\
\hline Volume required & $\begin{array}{c}10 * 15 * 0.065= \\
9.75\end{array}$ & $\begin{array}{c}0.006 * 10 * 15= \\
0.9\end{array}$ & $\begin{array}{l}0.004 * 10 * 15= \\
0.45 \mathrm{~m}^{3}\end{array}$ & $\begin{array}{c}\text { The hollow } \\
\text { segments should be } \\
\text { distributed over a } \\
\text { minimum of } 80 \% \text { of the } \\
\text { slab. } \\
\text { Volume required } \\
=10 * 15^{*} 0.15= \\
22.5^{*}(20 \%) \\
=4.5 \\
5 \text { slabs needed }\end{array}$ & $\begin{array}{c}\text { Volume required between } \\
\text { the } 5 \text { slabs is: } \\
0.1 * 0.25^{*} 15^{*} 5=1.1\end{array}$ \\
\hline Density (tons $/ \mathrm{m}^{3}$ ) & 1.2 & 1.5 & 0.92 & 0.80 & 1.9 \\
\hline Wastage rate & $5 \%$ & $5 \%$ & $10 \%$ & $10 \%$ & $10 \%$ \\
\hline $\begin{array}{c}\text { Quantity tones (with } \\
\text { wastage rate) }\end{array}$ & $\begin{array}{c}1.2 * 9.75+(12 * 9.7 \\
5 * 0.05)= \\
12.3\end{array}$ & $\begin{array}{c}1.2 * 0.9+(1 \\
2 * 0.9 * .05)= \\
1.1\end{array}$ & $\begin{array}{c}0.45 \\
* 0.92+(0.45 * \\
0.92 * 10 \%) \\
=0.45 \\
\end{array}$ & $\begin{array}{c}0.8^{*} \\
7.5+\left(0.8 * 7.5^{*} 0.1\right)=4\end{array}$ & $\begin{array}{c}1.1 * 1.9+(1.1 * 1.9 * 0.1)= \\
2.2\end{array}$ \\
\hline $\begin{array}{l}\text { Embodied energy } \\
\text { tCO2/ton material }\end{array}$ & 0.6 & 2.85 & 0.9 & 0.33 & 0.18 \\
\hline $\begin{array}{c}\text { Footprint (tons fossil } \\
\text { CO2e) }\end{array}$ & 7.4 & 3.1 & 0.9 & 2.28 & 0.88 \\
\hline $\begin{array}{c}\text { Embodied } \\
\mathrm{CO} 2+\text { material }\end{array}$ & \multicolumn{3}{|c|}{13.20 tons $\mathrm{CO} 2$} & \multicolumn{2}{|c|}{ (Cradle to gate) } \\
\hline Manufacturing site & $\begin{array}{l}\text { Roath Dock } \\
\text { Road, Cardiff, }\end{array}$ & $\begin{array}{c}\text { Penarth. C F64 } \\
21 \mathrm{~A}\end{array}$ & \begin{tabular}{|c|} 
Leighton \\
Buzzard, LU7 \\
\end{tabular} & $\begin{array}{l}\text { Hope construction } \\
\text { material, }\end{array}$ & $\begin{array}{l}\text { Hope construction } \\
\text { material, }\end{array}$ \\
\hline $\begin{array}{c}\text { Distance from (gate to } \\
\text { site) }\end{array}$ & $6.9 \mathrm{~km}$ & 7.4 & 223.2 & 7.0 & 7.0 \\
\hline Mode of travel & Road & Road & Road & Road & Road \\
\hline \begin{tabular}{|c|} 
Footprint (tons fossil \\
CO2e
\end{tabular} & 0.004 & 0.003 & 0.007 & 0.006 & 0.003 \\
\hline Total & \multicolumn{5}{|c|}{$\begin{array}{l}0.023 \text { tons } \mathrm{CO} 2 \text { by Transport of Materials (gate to site) } \\
\text { Cradle to site }:(13.2+0.021)=13.22 \text { tons } \mathrm{CO} 2\end{array}$} \\
\hline
\end{tabular}




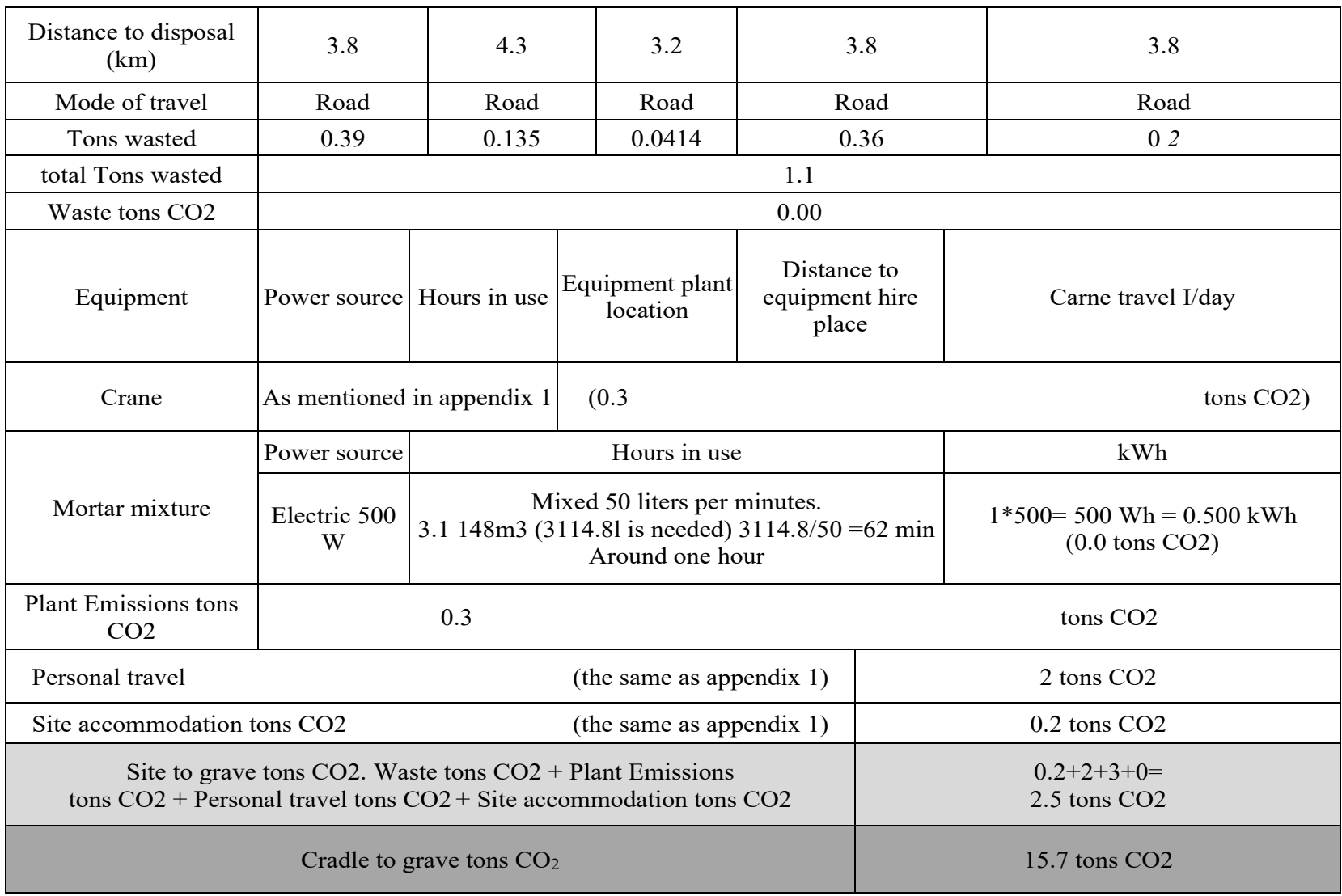


Appendix 3: summary of assumptions and calculations used to estimate the carbon footprint from cradle to grave for the precast solid slabs) concrete floor system

\begin{tabular}{|c|c|c|c|c|c|c|c|c|}
\hline \multicolumn{2}{|l|}{ Component } & \begin{tabular}{|} 
Screed \\
(sand and \\
cement)
\end{tabular} & \multicolumn{2}{|c|}{ Rubber } & $\begin{array}{c}\text { Vapor control } \\
\text { layer } \\
\text { (polyethylene) }\end{array}$ & \multicolumn{2}{|c|}{$\begin{array}{c}\text { Concrete } \\
\text { precast concrete solid floor } \\
\text { slabs } \\
\end{array}$} & Mortar \\
\hline \multicolumn{2}{|c|}{ Volume required } & \multicolumn{4}{|c|}{ The same as appendix 2} & \multicolumn{2}{|c|}{$\begin{array}{c}\text { Volume required }= \\
10^{*} 15^{*} 0.15= \\
22.5 *(20 \%)=4.5 \\
\text { volume of slab } \\
10 * 3 * 0.15 *(20 \%)=0.4 .5 \\
6 \text { slabs needed }\end{array}$} & $\begin{array}{l}\text { Volume required between the } 6 \\
\text { slabs is: } \\
\begin{array}{c}(0.1 * 10 * 0.1 * 4)+(0.1 * 0.1 * 15 * 3) \\
=0.85\end{array}\end{array}$ \\
\hline Density & & \multicolumn{4}{|c|}{ The same as appendix 2} & \multicolumn{2}{|c|}{$0.80\left(\right.$ tons $\left./ \mathrm{m}^{3}\right)$} & $1.9\left(\right.$ tons $\left./ \mathrm{m}^{3}\right)$ \\
\hline Wastage rat & & \multicolumn{4}{|c|}{ The same as appendix 2} & \multicolumn{2}{|c|}{$10 \%$} & $10 \%$ \\
\hline $\begin{array}{l}\text { Quantity } \\
\text { tones (with was } \\
\text { rate) }\end{array}$ & & \multicolumn{4}{|c|}{ The same as appendix 2} & \multicolumn{2}{|c|}{$0.8 * 22.5+(0.13 * 22.5 * 0.1)=6.6$} & $0.85 * 1.9+(0.135 * 1.9 * 0.1)=1.77$ \\
\hline $\begin{array}{l}\text { Embodied ene } \\
\text { tCO2/tons mat }\end{array}$ & $\begin{array}{l}\text { rgy } \\
\text { erial }\end{array}$ & \multicolumn{4}{|c|}{ The same as appendix 2} & \multicolumn{2}{|c|}{0.33} & 0.18 \\
\hline $\begin{array}{r}\text { Footprint (to } \\
\text { fossil CO2 } \\
\text { (transport) }\end{array}$ & & 7.4 & & 3.1 & 0.9 & \multicolumn{2}{|c|}{6.51} & 0.39 \\
\hline $\begin{array}{c}\text { Disposal } \\
\text { method }\end{array}$ & \multicolumn{8}{|c|}{ The same as appendix 2} \\
\hline $\begin{array}{l}\text { Distance to } \\
\text { disposal }\end{array}$ & \multicolumn{8}{|c|}{ The same as appendix 2} \\
\hline Mode of travel & \multicolumn{8}{|c|}{ The same as appendix 2} \\
\hline $\begin{array}{c}\text { Tons } \\
\text { wasted }\end{array}$ & 0.39 & \begin{tabular}{l|l}
9 & 0.135 \\
\end{tabular} & & & 10.0414 & $' 1.8$ & & 0.1615 \\
\hline total & \multicolumn{8}{|c|}{15 Tons wasted } \\
\hline Waste & \multicolumn{8}{|c|}{0.00} \\
\hline $\begin{array}{c}\text { Embodied } \\
\mathrm{CO} 2 \text { material } \\
\text { +waste }\end{array}$ & \multicolumn{8}{|c|}{18.3 tons $\mathrm{CO} 2$ (Cradle to gate) } \\
\hline $\begin{array}{c}\text { Manufacturing } \\
\text { site }\end{array}$ & \multicolumn{8}{|c|}{ The same as appendix 2} \\
\hline $\begin{array}{c}\begin{array}{c}\text { Distance from } \\
\text { (gate to site) }\end{array} \\
\end{array}$ & \multicolumn{8}{|c|}{ The same as appendix 2} \\
\hline Mode of travel & \multicolumn{8}{|c|}{ The same as appendix 2} \\
\hline $\begin{array}{c}\text { Footprint (tons } \\
\text { fossil CO2e } \\
\text { (transport) }\end{array}$ & & 0.004 & & 0.003 & 0.007 & 0.006 & & 0.003 \\
\hline Total & \multicolumn{8}{|c|}{$\begin{array}{l}0.023 \text { tons } \mathrm{CO} 2 \text { by Transport of Materials (gate to site) } \\
\text { Cradle to site: }(18.3+0.021)=18.32 \text { tons } \mathrm{CO} 2\end{array}$} \\
\hline \multicolumn{9}{|c|}{ Equipment } \\
\hline Crane & & \multicolumn{5}{|c|}{ As mentioned in appendix 2} & \multicolumn{2}{|r|}{$(0.3$ tons $\mathrm{CO} 2)$} \\
\hline \multirow[b]{2}{*}{ Mortar mixtur } & \multicolumn{3}{|c|}{ Power source } & & Hours in $\mathrm{u}$ & & & $\mathrm{kWh}$ \\
\hline & & Electric 50 & & 1.771 & $\begin{array}{l}\text { Tixed } 50 \text { liters pe } \\
3 \text { (1770.1 is neec } \\
=35 \mathrm{~min} \text { Aroun }\end{array}$ & $\begin{array}{l}\text { minutes. } \\
\text { d) } 3114.8 / 50 \\
0.52\end{array}$ & $0.5 * 500$ & $\begin{array}{l}=250 \mathrm{Wh}=0.250 \mathrm{kWh} \\
(0.0 \text { tons } \mathrm{CO} 2)\end{array}$ \\
\hline Plant Emissio & & & & & & 0.3 tons & & \\
\hline Personal travel & & & & & (the same as appe & $\operatorname{dix} 2)$ & & tons $\mathrm{CO} 2$ \\
\hline Site accommod & ation $\mathrm{t}$ & tons $\mathrm{CO} 2$, & & & (the same as appe & $\operatorname{dix} 2)$ & & 2 tons $\mathrm{CO} 2$ \\
\hline $\begin{array}{r}\text { Site to gra } \\
\text { tons } \mathrm{CO} 2+\mathrm{P}\end{array}$ & $\begin{array}{l}\text { ve ton } \\
\text { erson }\end{array}$ & $\begin{array}{l}\text { ns } \mathrm{CO} 2 . \mathrm{W} \\
\text { hal travel to }\end{array}$ & & $\begin{array}{l}\text { ons C } \\
\mathrm{O} 2, \mathrm{Si}\end{array}$ & $\begin{array}{l}\text { 2. Plant Emissio } \\
\text { accommodation }\end{array}$ & & & $\begin{array}{l}+24 \% 3+0= \\
5 \text { tons } \mathrm{CO} 2\end{array}$ \\
\hline
\end{tabular}

